\title{
Management Changes And Performance: The Case Of REITs
}

Russell M. Price, Howard University, USA

\begin{abstract}
Management's (board of directors or executive officers) contribution to a firm is difficult to directly observe, although stock return performance can be a source of information. This study extends the work of McIntosh et al (1994) and Friday et al (2006) by analyzing management changes involving Real Estate Investment Trusts from 1996 to 2008. I find that there is a significant relationship between negative performance and a management change from a period three months prior to the change in management. REITs specializing in office properties have the largest negative performance prior to management changes. Negative performance prior to management changes was highest during the tech bubble period.
\end{abstract}

Keywords: Management Changes; Board Composition; REITs

\section{INTRODUCTION}

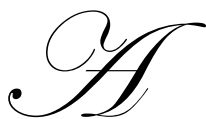

company experiences various significant events during its existence, good or bad. These events lead to management turnover in the company, such as changes in the structure of the board or executive management. In some cases, top management departs as a result of a better offer from raiding firms buying away good talent (Fee et al 2003). Another reason for changes is the opportunity to move to a position better suited to the individual's talents. In many cases, changes in management improves overall firm performance. This, of course, implies that the previous performance of the firm was not meeting expectations.

Top management in a firm is identified by its board structure and executive management structure. Typical board makeup consists of the Chairman, Vice-Chairman, Trustees and other Directors. Executive management usually includes the Chief Executive Officer (CEO), Chief Operating Officer (COO), Chief Financial Officer (CFO), President, Vice President, and other officers.

McIntosh et al (1994) produced the first study on the performance of Real Estate Investment Trusts (REITs) and their ability to predict changes in management. They found an inverse relationship between firm performance and the probability of a management change. Their study included 55 REITs established by 1990 . My study extends their work and the work of Friday et al (2006) by analyzing the performance of 156 REITs based on performance measures centered on events from years 1996 to 2008. This time period includes the effects of the huge REIT boom from 1996 to 1998, the Internet bubble of 1998 to 2000, the Internet bubble crash from 2000 to 2002, the post-bubble crash of 2002 to 2004, the housing bubble of 2004 to 2007, and the housing bubble crash of 2007 to 2008.

REITs have been in place since the 1970s. Their purpose was twofold: give investors another vehicle to invest in real estate, and offer firms and asset holders a tax relief incentive for their real estate holdings. Regulation requires that $90 \%$ of a REIT's profits must be distributed to stockholders. This requirement is the primary stipulation for the tax relief.

The management structure of REITs is slightly different from the typical corporation. The upper management (directors, trustees, or employees) of a REIT cannot actively engage in managing REIT property, but can engage in day-to-day operations. Usually independent and external real estate professionals manage the REIT properties. A measure of firm performance can be evaluated in an efficient market. If the firm is performing badly, 
a change in management is in order. Negative performance in comparison to the market should signal a management change. I look to identify negative performance in a firm prior to a change in management, and positive performance after the change event short-term.

\section{THE LITERATURE ON MANAGEMENT TURNOVER}

Furtado and Karan (1990) provide a detailed review and summary of various empirical studies of the causes, consequences and market effects of management turnover for typical corporations. Studies examine internal forces monitoring management performance such as the board of directors (Fama 1980), competing managers (Fama and Jensen 1983) and block shareholders (Shleifer and Vishny 1986). Results show an inverse relationship between firm performance and management turnover (Warner, Watts and Wruck 1988). The relationship generally weakens when the manager acquires power through family ties or stock ownership. Firms that have outsider-dominated boards tend to have a strong relationship between firm performance and turnover (Weisbach 1988). Devos et al (2009) report that shareholders respond negatively to interlocked boards; the presence of such boards create reduced sensitivity to CEO turnover to firm performance. Fischer et al (2010) find an inverse relationship between board turnover and vote approval of uncontested director elections. Voting serves as a proxy for investor perception of firm performance.

Following several early studies concerning CEO turnover (see Coughlan and Schmidt, 1985; Warner et al., 1988; Weisbach, 1988), an extensive literature on this topic has evolved. ${ }^{1}$ These studies establish that CEOs tend to be replaced when their firms are performing poorly. Furthermore, they demonstrate that there is substantial heterogeneity across firms in the sensitivity of CEO turnover to firm performance depending on factors such as board composition, bank monitoring, and takeover pressure. The sensitivity of CEO turnover to firm performance is usually interpreted as an indication that boards or other monitors hold CEOs responsible for poor corporate performance and that they dismiss underperforming CEOs in order to increase corporate value.

Forced resignations of top managers are generally preceded by large declines in performance and followed by sharp increases. However, normal resignations show minimal effect (Denis and Denis 1995). Fee and Hadlock (2004) find CEO turnover from poor performance no different from non-CEO turnover; performance has limited sensitivity to poor performance. Additionally CEO dismissals lead to dismissal of non-CEOs. The length of CEO tenure can affect performance. Allgood and Farrell (2000) find that a constant negative relationship between performance and forced turnover exists throughout an entrenched CEO's tenure. The result becomes more pronounced after ten years. They use Return on Assets (ROA) instead of stock returns as a measure of performance. Camatta and Guembel (2010) determine managerial turnover after poor performance is less likely when a legacy exists and entrenchment is strong.

Top executive turnover can be greatly affected by ownership structure; an inverse relationship exists between turnover and the ownership stake of officers and directors. A positive relationship exists between turnover and outside blockholders (Denis, Denis, and Sarin 1997). CEO succession leads to an increased probability of outside director turnover (Farrell and Whidbee 2000). Parrino (1997) shows that the likelihood or frequency in CEO turnover/outside succession increases with the level of homogeneity across industries. If the CEO is involved with selecting new board members, stock price reaction is typically lower (Shivdasani and Yermack 1999). Greater representation on REIT boards by outside directors has a positive effect on performance (Ghosh and Sirmans 2003).

Higher management turnover occurs following mergers, acquisitions, tender offers, proxy fights and negotiated block trades (Klein and Rosenfeld 1988; Martin and McConnell 1989; and Barclay and Holderness 1989). Unsuccessful tender offers can still prompt management turnover, as the offer signals potential change (DeAngelo and DeAngelo 1989). Positive firm performance, appearing after the payment of "greenmail" (stock repurchases on favorable terms) leads to above average turnover one year after the payment (Klein and Rosenfeld 1988). Contradictory results exist among studies of share price effects around the announcement of management turnover (Reinganum 1985; Bonnier and Bruner 1989; Warner, Watts and Wruck 1988; and Weisbach 1988).

\footnotetext{
${ }^{1}$ A partial list of relevant studies includes Gilson (1989), Kang and Shivdasani (1995), Hadlock and Lumer (1997), Mikkelson and Partch (1997), Perry (1999), Defond and Park (1999), Fee and Hadlock (2000), Huson et al. (2001), Goyal and Park (2002), and Murphy and Zimmerman (2003).
} 


\section{TESTABLE HYPOTHESES}

Top managers' contributions to the firm cannot be directly observed. However, stock returns can be a potential source of information. McIntosh et al (1994) performs a joint test on the hypothesis that information about management performance is reflected in stock returns, and the return information is then used to evaluate performance. Poor performance is implied from declining or negative stock returns, on an absolute level or in relation to the market. If poor performance is persistent, then a change in management will occur. The manager may be fired, reassigned or "suggested" to resign. New management will come either from within via a promotion, or "new blood" will be imported from the outside. Poor performance can lead to changes on the board level as well.

Management change can also occur when the firm is doing well. Superior performance by management could lead to promotions. Also, the firm's good fortune can put managers in a position of strength, making them attractive to outsiders. Managers may leave as a result of a successful management raid (Fee et al 2003).

My hypothesis is that poor performance, measured by negative cumulative abnormal returns (CAR), will lead to a management change:

H0: $\quad$ CAR $=0$.

My study looks at the return of the subject firms in relation to the market (equal-weighted and valueweighted returns). I find evidence of mean CARs (using an equal-weighted market index) ranging from $-1.46 \%$ to $1.80 \%$ over a period three months prior to ten days after the announcement of a change in management. The conclusions are similar to those by Friday et al (2006). Large-cap firms produce strong positive CARs; this is evidenced by the results generated using a value-weighted market index. Office REITs have strong negative performance during periods starting three months, two weeks and one day prior the change announcement. Management changes have no effect on REIT performance during the IPO period and have the highest negative performance during the tech bubble period.

\section{DATA}

My database contains 1,773 management changes within 156 REITs from 1996 to 2008. The distribution of events and REITs by year is displayed in Table I. These stocks trade on the NYSE, AMEX and NASDAQ. The changes in management are identified from the Wall Street Journal Index, Lexis-Nexis, Business Newswire, PR Newswire, Southwest Newswire, and the SNL Financial real estate module. I next identify the type of individual that was affected by the change. Board position changes included Chairman of the Board, Vice-Chairman of the Board, Directors, or Trustees. Corporate position changes (officer) included Chief Executive Officer, Chief Operating Officer, Chief Financial Officer, President, or Vice President. Multiple individuals within the Director, Trustee, or Vice President categories were treated as one individual in that category. Multiple changes within the Board or Corporate category were treated as one.

\section{METHODOLOGY}

My analysis is performed in two stages. First, I want to determine which management changes have the most profound effect and are easiest to predict: changes in the board structure or corporate structure (officers). Since the corporate structure is most closely involved in the day-to-day operations of the firm, it would produce the most influence on performance, and should create a greater contribution to management change. Second, I look at the type of change and its relation to performance. Change is evaluated in three categories: announcement/appointment (annapp), hire, and resign. Promotions from within are classified as announcements/appointments. Elections of present board members to new positions (existing board member becomes vice-chairman, for example) are classified as announcements/appointments. If the election involved an outsider, then it is classified as hire. The resign category is classified as forced departure (firings and dismissals are included), although events such as death are included. The hire category captures the effect of outsiders. 
Table I: Management Changes

Annual Listing of Management Changes at Real Estate Investment Trusts from 1996-2008

\begin{tabular}{|c|c|c|}
\hline Year & Changes & REITs \\
\hline 1996 & 54 & 31 \\
\hline 1997 & 66 & 35 \\
\hline 1998 & 96 & 44 \\
\hline 1999 & 99 & 51 \\
\hline 2000 & 94 & 47 \\
\hline 2001 & 90 & 44 \\
\hline 2002 & 100 & 56 \\
\hline 2003 & 157 & 63 \\
\hline 2004 & 143 & 67 \\
\hline 2005 & 199 & 86 \\
\hline 2006 & 238 & 80 \\
\hline 2007 & 260 & 94 \\
\hline 2008 & 176 & 66 \\
\hline
\end{tabular}

As stated previously, the performance level of top management is not directly observable, thus stock returns are used as a measure of performance. To examine the effect of poor performance management change, return performance measures (equal and value-weighted returns) are compiled from CRSP, starting one year prior to the date of the management change. Cumulative abnormal returns are analyzed for a window three months before the event date to one day after the event date $[-65,+1]$. The effect of change two weeks prior to the event date to immediately after the event is also examined $[-10,+1]$. I check for the short-term information effects of the event by looking at a $[-1,+1]$ window. I also look at windows of $[-65,+10],[-10,+10]$ and $[-1,+10]$ to check for any postevent information effects. Similar to the estimation technique of Brown and Warner (1985), I create an estimation window from one year prior to three months prior [-265, -66]. I use the time-series standard deviation test to generate my one-tailed t-statistics, per Brown and Warner (1980, 1985). My results predict that a change in management is preceded by negative CAR and followed by positive CAR.

The data is also analyzed from a sector and time period perspective. I look at the major REIT industry sectors (healthcare, hotel, industrial/diversified, office, residential and retail). I partition the data into time periods: REIT IPO boom (1/1/1996-12/31/1997); tech bubble (1/1/1998-3/31/2000); tech bubble crash (4/1/2000-9/30/2002); post-bubble crash (10/1/2002-3/31/2004); housing bubble (4/1/2004-3/31/2007); housing bubble crash (4/1/200712/31/2008).

\section{RESULTS}

Management change announcements, along with the REITs involved, are distributed by year and shown in Table I. The maximum number of announcements and REITs involved occurred during the housing bubble period. Mortgage activity was at its peak, property values and acquisitions were high, and REITs found it necessary to place upper management in position to best handle the increased activity.

The segregation of announcements by management type (board and officer), and event type (announcements/appointment (denoted annapp), hire and resign) are listed annually in Table II. The most striking result is the large increase in board announcements from 2002 to 2003. This period coincides with the SarbanesOxley legislation of mid-2002; one of the principal aspects of Sarbanes-Oxley was change in board composition. 
Table II: Management Changes

Annual Listing of Analyzed Management Changes at Real Estate Investment Trusts, by category, from 1996-2008

\begin{tabular}{|c|c|c|c|c|c|c|}
\hline Year & All Events & AnnApp & Board & Hire & Officer & Resign \\
\hline 1996 & 54 & 30 & 24 & 13 & 30 & 5 \\
\hline 1997 & 66 & 35 & 26 & 13 & 40 & 8 \\
\hline 1998 & 97 & 25 & 28 & 30 & 69 & 21 \\
\hline 1999 & 99 & 21 & 29 & 37 & 70 & 18 \\
\hline 2000 & 94 & 30 & 22 & 29 & 72 & 17 \\
\hline 2001 & 90 & 32 & 35 & 33 & 55 & 14 \\
\hline 2002 & 100 & 35 & 34 & 39 & 66 & 15 \\
\hline 2003 & 157 & 79 & 87 & 33 & 70 & 29 \\
\hline 2004 & 143 & 55 & 68 & 38 & 75 & 35 \\
\hline 2005 & 199 & 58 & 65 & 64 & 134 & 41 \\
\hline 2006 & 238 & 71 & 79 & 84 & 159 & 51 \\
\hline 2007 & 260 & 87 & 98 & 75 & 162 & 32 \\
\hline 2008 & 176 & 68 & 67 & 48 & 109 & 22 \\
\hline Total & 1773 & 626 & 662 & 536 & 1111 & 308 \\
\hline
\end{tabular}

Table III is used for the results of my statistical analysis, testing how cumulative abnormal returns (CARs) are significantly different from zero over varying event windows. The abnormal returns are market-adjusted using equal-weighted market returns.

For a period of three months prior to the announcement of a management change, performance has a significant effect on management changes overall. There is a $-1.62 \%$ CAR over the $[-65,+1]$ window indicating that negative firm performance will lead to a management change. Negative performance has a significant effect on change in board $(-1.60 \%)$ and officer $(-1.46 \%)$ structure. Performance also has a significant influence on the type of event. Changes that involved an announcement or appointment have a $-1.61 \%$ CAR. Forced departures (actual, or "reported" resignations, firings, and dismissals) have a $-1.72 \%$ CAR. The effect of changes that brought in outsiders (hire) is negative, but insignificant. When the event window is extended to ten days after the management change to test for the effects post-event, and find increased negative effects of performance around the event, with the exception of hires. These results imply continued negative response to the management change in the short-term period after the event occurs. The results are consistent with those determined by Friday et al (2006); the behavior of management changes on REIT performance is consistent over an additional five years of events.

I next examine how performance measured two weeks prior to the management change affects the event. By this time a decision probably has been made on the imminent changes (death being an exception, especially if sudden), so I would expect a smaller effect. I find that the effect of performance on the overall sample is generally insignificant, with the exception of a $-0.1 \%$ CAR for announcements/appointments and $+0.61 \%$ for hires, implying that maybe the decision of change probably has occurred earlier than two weeks before the change.

The next analysis determines how performance one day prior to the management change affects the event. I find that the effect of performance on the overall sample is generally insignificant, with the exception of a $+0.27 \%$ CAR for announcements/appointments and $+0.25 \%$ for board members. The results imply that the positive effect of the management change is immediate. The changes involving officers have a CAR of $+0.49 \%$. 
Table III: Performance Around Management Change (Equal-Weighted)

Cumulative Abnormal Return (CAR) Performance on Event Windows Around Management Change Announcements of REITs from 1996 to 2008

(mean returns shown, followed by CDA t-stats per Brown and Warner (1980))

\begin{tabular}{|c|c|c|c|c|c|c|}
\hline & & & \\
\hline \multirow{2}{*}{$\begin{array}{l}\text { Window } \\
{[-65+1]}\end{array}$} & \multicolumn{2}{|c|}{\begin{tabular}{l|l} 
All Changes & AnnApp
\end{tabular}} & Board & Hire & Officer & Resign \\
\hline & -1.62 & -1.61 & -1.60 & -0.39 & -1.46 & -1.72 \\
\hline$[-65,+1]$ & $* * *-4.73$ & $* *-2.35$ & $* * *-2.80$ & -0.68 & $* * *-3.50$ & $*-1.69$ \\
\hline \multirow[t]{2}{*}[-65,+10]{} & -1.68 & -1.73 & -1.73 & -0.10 & -1.51 & -1.83 \\
\hline & $* * *-4.62$ & $* *-2.38$ & $* * *-2.83$ & -0.16 & $* * *-3.40$ & $*-1.70$ \\
\hline \multirow[t]{2}{*}[-10,+1]{} & -0.02 & -0.23 & 0.19 & 0.32 & 0.01 & 0.09 \\
\hline & -0.12 & -0.78 & 0.80 & 1.34 & 0.07 & 0.22 \\
\hline \multirow[t]{2}{*}[-10,+10]{} & -0.08 & -0.10 & 0.07 & 0.61 & -0.04 & -0.02 \\
\hline & -0.42 & $* * *-2.67$ & 0.22 & $* 1.92$ & -0.16 & -0.04 \\
\hline \multirow[t]{2}{*}[-1,+1]{} & 0.03 & 0.27 & 0.25 & -0.02 & 0.20 & 0.16 \\
\hline & 0.39 & $* * 1.97$ & $* * 2.09$ & -0.18 & 1.52 & 0.73 \\
\hline \multirow[t]{2}{*}[-1,+10]{} & -0.05 & 0.13 & 0.11 & -0.09 & 0.49 & 0.05 \\
\hline & -0.37 & 0.46 & 0.47 & -0.49 & $* 1.86$ & 0.11 \\
\hline
\end{tabular}

* Significance at $10 \%$ level

**Significance at $5 \%$ level

$* * *$ Significance at $1 \%$ level

Overall, performance measures three months prior to the change are significant. Announcements/appointments are significant at periods from three months to ten days before the management change. Changes in officer structure produce more profound effects up to ten days after the management change.

I use Table IV to show results using value-weighted market returns. I find the sample has significant positive CARs across all event windows. This suggests an extensive contribution by large-cap firms with positive CARs. Only the hire category and the officer category are significant over the three-month event window. New hire events produce CARs of +2.23 over $[-65,+1]$ and +2.74 over $[-65,+10]$. Events involving officers produce smaller CARs over similar windows ( +0.75 and 0.89 respectively).

At a period two weeks before the event positive CARs exist across all categories except resign. Positive CARs are smaller over these windows than the three-month window. The CARs vary from +0.37 in the officer category over the $[-10,+1]$ window to +1.28 in the hires category over the $[-10,+10]$ window.

I investigate the windows starting one day before the event and find CARs over the $[-1,+1]$ window have values of $+0.37 \%$ in the announcement/appointment category, $+0.33 \%$ in both the board and officer category. CARs over the $[-1,+10]$ window have values of $+0.68 \%$ in the announcement/appointment category, $+0.54 \%$ in the board category and $+0.82 \%$ in officer category.

Events that involved departures are not significant in this analysis.

\section{CUMULATIVE ABNORMAL RETURNS BY SECTOR}

Most REITs concentrate their property holdings in a specific type, or sector. These sectors carry different cap rates and as a result different levels of risk. If the risk levels are different then the responses to management changes are different as well. 
Table IV: Performance Around Management Change (Value-Weighted)

Cumulative Abnormal Return (CAR) Performance on Event Windows Around Management Change Announcements of REITs from 1996 to 2008

(mean returns shown, followed by CDA t-stats per Brown and Warner (1980))

\begin{tabular}{|c|c|c|c|c|c|c|}
\hline Window & All Changes & AnnApp & Board & Hire & Officer & Resign \\
\hline$[-\mathbf{- 6 5},+\mathbf{1}]$ & 0.61 & 0.81 & 0.73 & 2.23 & 0.75 & 0.38 \\
\hline & $* 1.69$ & 1.12 & 1.20 & $* * * 3.69$ & $* 1.72$ & 0.35 \\
\hline$[-\mathbf{6 5},+\mathbf{1 0}]$ & 0.79 & 1.13 & 0.95 & 2.74 & 0.89 & 0.37 \\
\hline & $* * 2.05$ & 1.47 & 1.47 & $* * * 4.26$ & $* 1.92$ & 0.32 \\
\hline$[-\mathbf{- 1 0},+\mathbf{1}]$ & 0.37 & 0.72 & 0.62 & 0.77 & 0.37 & 0.33 \\
\hline & $* * 2.41$ & $* * 2.35$ & $* * 2.42$ & $* * * 3.01$ & $* * 2.01$ & 0.74 \\
\hline$[-\mathbf{1 0},+\mathbf{1 0}]$ & 0.55 & 1.05 & 0.84 & 1.28 & 0.51 & 0.32 \\
\hline & $* * * 2.71$ & $* * 2.57$ & $* * 2.48$ & $* * * 3.79$ & $* * 2.10$ & 0.54 \\
\hline$[-\mathbf{1},+\mathbf{1}]$ & 0.13 & 0.37 & 0.33 & 0.10 & 0.33 & 0.18 \\
\hline$[-1,+10]$ & $* 1.66$ & $* * 2.57$ & $* * * 2.67$ & 1.15 & $* * 2.45$ & 0.80 \\
\hline & 0.29 & 0.68 & 0.54 & 0.22 & 0.82 & 0.16 \\
\hline
\end{tabular}

* Significance at $10 \%$ level

**Significance at $5 \%$ level

*** Significance at $1 \%$ level

I use Table V to show event study results over the six sectors with the most REITs: healthcare, hotel, industrial, office, residential and retail. Table V shows CARs with equal-weighted market data.

Table V: Performance Around Management Change by Sector (Equal-Weighted)

Cumulative Abnormal Return (CAR) Performance on Event Windows Around Management Change Announcements of REITs from 1996 to 2008

(mean returns shown, followed by CDA t-stats per Brown and Warner (1980))

\begin{tabular}{|c|c|c|c|c|c|c|}
\hline Window & Healthcare & Hotel & Industrial & Office & Residential & Retail \\
\hline & $(\mathrm{N}=144)$ & $(\mathrm{N}=110)$ & $(\mathrm{N}=146)$ & $(\mathrm{N}=106)$ & $(\mathrm{N}=245)$ & $(\mathrm{N}=301)$ \\
\hline$[-\mathbf{- 6 5},+\mathbf{1}]$ & 2.37 & -3.62 & -4.00 & -2.78 & -0.82 & -0.65 \\
\hline & $* 1.84$ & $* * *-2.63$ & $* * *-4.11$ & $* *-2.36$ & -1.20 & -0.82 \\
\hline$[-\mathbf{- 6 5},+\mathbf{1 0}]$ & 2.44 & -3.31 & -3.55 & -3.22 & -1.08 & -0.83 \\
\hline & $* 1.78$ & $* *-2.26$ & $* * *-3.43$ & $* *-2.56$ & -1.49 & -0.98 \\
\hline$[-\mathbf{1 0},+\mathbf{1}]$ & 0.61 & 0.82 & -0.58 & -1.43 & -0.38 & 1.11 \\
\hline & 1.13 & 1.43 & -1.42 & $* * *-2.86$ & -1.31 & $* * * 3.30$ \\
\hline$[-\mathbf{- 1 0}+\mathbf{+ 1 0}]$ & 0.68 & 1.13 & -0.14 & -1.86 & -0.65 & 0.93 \\
\hline & 0.94 & 1.47 & -0.25 & $* * *-2.82$ & $*-1.69$ & $* * 2.09$ \\
\hline$[-\mathbf{- 1}+\mathbf{+ 1}]$ & 0.91 & 0.16 & 0.31 & -0.68 & -0.14 & 0.40 \\
\hline & $* * * 3.33$ & 0.54 & 1.48 & $* * *-2.74$ & -0.98 & $* * 2.39$ \\
\hline$[-1,+10]$ & 0.97 & 0.46 & 0.75 & -1.12 & -0.41 & 0.22 \\
\hline & $* 1.79$ & 0.80 & $* 1.83$ & $* *-2.24$ & -1.41 & 0.66 \\
\hline
\end{tabular}

* Significance at $10 \%$ level

$* *$ Significance at $5 \%$ level

*** Significance at $1 \%$ level

The only positive CARs over the $[-65,+1]$ window are in the healthcare sector $(+2.37 \%)$. Negative CARs are present in the hotel $(-3.31 \%)$, industrial $(-4.00 \%)$ and office $(-2.78)$ sectors. Results are similar over the [-65, +10 ] window. 
The significant CARs over the $[-10,+1]$ window are in the office $(-1.43 \%)$ and retail $(+1.11)$ sectors. The CARs over the $[-10,+10]$ window are $-1.86 \%$ in the office sector and $+0.93 \%$ in the retail sector.

The significant CARs over the $[-1,+1]$ window are in the healthcare $(+0.91 \%)$, office $(-0.68 \%)$ and retail $(+0.40)$ sectors. The CARs over the $[-1,+10]$ window are $+1.86 \%$ in the healthcare sector, $+0.75 \%$ in the industrial sector and $+0.22 \%$ in the retail sector.

I use Table VI to show CARs with value-weighted market data. The only negative CARs over the $[-65,+1]$ window are in the industrial sector $(-1.98 \%)$. Positive CARs are present in the healthcare $(+4.64 \%)$ and residential $(+2.64)$ sectors. Results are similar over the $[-65,+10]$ window; the industrial sector results are no longer significant.

Table VI: Performance Around Management Change by Sector (Value-Weighted)

Cumulative Abnormal Return (CAR) Performance on Event Windows Around Management Change Announcements of REITs from 1996 to 2008

(mean returns shown, followed by CDA t-stats per Brown and Warner (1980))

\begin{tabular}{|c|c|c|c|c|c|c|}
\hline Window & Healthcare & Hotel & Industrial & Office & Residential & Retail \\
\hline & $(\mathrm{N}=144)$ & $(\mathrm{N}=110)$ & $(\mathrm{N}=146)$ & $(\mathrm{N}=106)$ & $(\mathrm{N}=245)$ & $(\mathrm{N}=301)$ \\
\hline$[-\mathbf{- 6 5},+\mathbf{1}]$ & 4.64 & -1.65 & -1.98 & -0.13 & 2.64 & 1.23 \\
\hline & $* * * 3.54$ & -1.18 & $*-1.93$ & -0.10 & $* * * 3.62$ & 0.35 \\
\hline$[-\mathbf{- 6 5},+\mathbf{1 0}]$ & 4.95 & -1.35 & -1.27 & -0.24 & 2.84 & 1.30 \\
\hline & $* * * 3.54$ & -0.90 & -1.26 & -0.18 & $* * * 3.66$ & 0.32 \\
\hline$[-\mathbf{- 1 0},+\mathbf{1}]$ & 1.86 & 1.10 & -0.30 & -0.74 & 0.36 & 1.29 \\
\hline & $* * 2.08$ & $* 1.84$ & -0.70 & -1.41 & 1.15 & 0.74 \\
\hline$[-\mathbf{1 0},+\mathbf{1 0}]$ & 1.47 & 1.40 & 0.41 & -0.85 & 0.56 & 1.35 \\
\hline & $* * 2.00$ & $* 1.79$ & 0.72 & -1.22 & 1.38 & $* * 2.85$ \\
\hline$[-\mathbf{1 , + 1}]$ & 0.93 & 0.26 & 0.40 & -0.51 & 0.08 & 0.46 \\
\hline & $* * 3.34$ & 0.87 & $* 1.85$ & $*-1.94$ & 0.53 & $* * 2.55$ \\
\hline$[-1,+10]$ & 1.24 & 0.57 & 1.12 & -0.62 & 0.29 & 0.52 \\
\hline & $* * 2.23$ & 0.96 & $* * 2.57$ & -1.18 & 0.94 & 1.46 \\
\hline
\end{tabular}

* Significance at $10 \%$ level

$* *$ Significance at $5 \%$ level

*** Significance at $1 \%$ level

The significant CARs over the $[-10,+1]$ window are in the healthcare $(+1.86 \%)$ and hotel $(+1.10)$ sectors. The CARs over the $[-10,+10]$ window are $+1.47 \%$ in the healthcare sector, $+1.40 \%$ in the hotel sector and $+1.35 \%$ in the retail sector.

The significant CARs over the $[-1,+1]$ window are in the healthcare $(+0.93 \%)$, industrial $(+0.40 \%)$, office $(-0.51 \%)$ and retail $(+0.46)$ sectors. The CARs over the $[-1,+10]$ window are $+1.24 \%$ in the healthcare sector and $+1.12 \%$ in the industrial sector.

\section{CUMULATIVE ABNORMAL RETURNS BY PERIOD}

The sample period covers multiple shifts in the economy. There is the REIT IPO boom (1/1/1996$12 / 31 / 1997)$, the tech bubble (1/1/1998-3/31/2000), tech bubble crash (4/1/2000-9/30/2002), crash recovery (10/1/2002-3/31/2004), the housing bubble (4/1/2004-3/31/2007) and housing bubble crash (4/1/2007-12/31/2008). Table VII shows CARs with equal-weighted market data.

The only insignificant CARs over the $[-65,+1]$ window are during the REIT IPO period. The only positive CARs are during the tech crash period $(+4.19 \%)$. Negative CARs are present during the tech bubble $(-11.55 \%)$, post-crash $(-5.74 \%)$ housing bubble $(-1.43 \%)$ and housing bubble crash $(-2.09 \%)$ periods. CARs are slightly different over the $[-65,+10]$ window, ranging from $-12.96 \%$ during the tech bubble period and $+4.93 \%$ during the tech crash period. 
The only insignificant CARs over the $[-10,+1]$ window are during the REIT IPO period. I still find positive CARs $(+1.46 \%)$ during the tech crash period. Negative CARs are present during the tech bubble $(-2.55 \%)$ and post-crash $(-0.72 \%)$ periods. The CARs over the $[-10,+10]$ window are $-3.92 \%$ during the tech bubble period, $+2.19 \%$ during the tech crash period, $-1.67 \%$ during the post-crash period and $-0.82 \%$ during the housing bubble crash period.

The only negative CARs over the $[-1,+1]$ window are during the tech bubble period $(-0.91 \%)$. The tech crash and housing bubble crash periods have CARs of $+0.66 \%$ and $+0.42 \%$, respectively. The CARs over the $[-1$, +10 ] window are $-2.29 \%$ over the tech bubble period, $+1.40 \%$ over the tech crash period, $-1.22 \%$ over the post-crash period, and $+0.78 \%$ over the housing bubble crash period.

Table VII: Performance Around Management Change by Period (Equal-Weighted)

Cumulative Abnormal Return (CAR) Performance on Event Windows Around Management Change Announcements of REITs from 1996 to 2008

(mean returns shown, followed by CDA t-stats per Brown and Warner (1980))

\begin{tabular}{|c|c|c|c|c|c|c|}
\hline Window & REIT IPO & Tech Bubble & Tech Crash & Post-Crash & RE Bubble & RE Crash \\
\hline & $(\mathrm{N}=131)$ & $(\mathrm{N}=200)$ & $(\mathrm{N}=226)$ & $(\mathrm{N}=215)$ & $(\mathrm{N}=612)$ & $(\mathrm{N}=344)$ \\
\hline$[-\mathbf{- 6 5},+\mathbf{1}]$ & -1.94 & -11.55 & 4.19 & -5.74 & -1.43 & -2.09 \\
\hline & -1.55 & $* * *-10.10$ & $* * * 3.39$ & $* * *-5.57$ & $* * *-3.08$ & $* * *-2.67$ \\
\hline$[-\mathbf{- 6 5},+\mathbf{+ 1 0}]$ & -2.25 & -12.96 & 4.93 & -6.69 & -1.58 & -1.73 \\
\hline & $*-1.68$ & $* * *-10.61$ & $* * * 3.74$ & $* * *-6.09$ & $* * *-3.18$ & $* *-2.08$ \\
\hline$[-\mathbf{1 0},+\mathbf{+ 1}]$ & 0.13 & -2.55 & 1.46 & -0.72 & 0.22 & 0.47 \\
\hline & 0.24 & $* * *-5.25$ & $* * * 2.78$ & $*-1.65$ & 1.11 & 1.43 \\
\hline$[-\mathbf{1 0},+\mathbf{1 0}]$ & -0.18 & -3.92 & 2.19 & -1.67 & 0.36 & 0.82 \\
\hline & -0.26 & $* * *-6.11$ & $* * * 3.17$ & $* * *-2.90$ & 1.39 & $* 1.88$ \\
\hline$[-\mathbf{- 1},+\mathbf{+ 1}]$ & 0.03 & -0.91 & 0.66 & -0.27 & -0.02 & 0.42 \\
\hline & 0.11 & $* * *-3.76$ & $* * 2.52$ & -1.22 & -0.19 & $* * 2.34$ \\
\hline$[-\mathbf{- 1 , + 1 0}]$ & -0.28 & -2.29 & 1.40 & -1.22 & 0.13 & 0.78 \\
\hline & -0.53 & $* * *-4.71$ & $* * * 2.67$ & $* * *-2.79$ & 0.64 & $* * 2.56$ \\
\hline
\end{tabular}

* Significance at $10 \%$ level

**Significance at $5 \%$ level

*** Significance at $1 \%$ level

I use Table VIII to show CARs with value-weighted market data. Positive and negative CARs have increased magnitude throughout. Only the REIT IPO period is without significant CARs.

\section{CONCLUSIONS}

Management's effects on REIT performance cannot be directly observed. Stock returns provide a source of information. I analyze 1,773 management changes affecting 156 REITs from 1996 to 2008. My purpose is to determine if negative performance, measured by cumulative abnormal returns (CAR), lead to a management change. I measure the effects of performance over several categories: announcement /appointments, hires (including elections to board), and forced departures (resignations). I also measure performance in relationship to changes on board structure and officer structure. I find that at a period of three months prior to the management change, negative performance $(-1.72 \%)$ is significant across the entire sample and all aforementioned categories except hires. When the performance is measured up to ten days after the change announcement, it shows an increased effect $(-1.83 \%)$. At ten days prior to changes, the level of negative performance moves toward zero. In addition, the results are less significant. This suggests that the effects of the proposed change have already been accounted for. Negative performance is most evident among office REITs $(-3.22 \%$ over the $[-65,+10]$ event window). Healthcare REITs show positive performance $(+2.44 \%)$, contrary to my hypothesis. The greatest negative performance is evident in the tech bubble period $(-12.96 \%)$. Performance measured with a value-weighted return measure is skewed toward large-cap firms with positive returns. 
Table VIII: Performance Around Management Change by Period (Value-Weighted) Cumulative Adjusted Abnormal Return (CAR) Performance on Event Windows Around Management Change Announcements of REITs from 1996 to 2008

(mean returns shown, followed by CDA t-stats per Brown and Warner (1980))

\begin{tabular}{|l|c|c|c|c|c|c|}
\hline \multicolumn{1}{|c|}{ Window } & REIT IPO & Tech Bubble & Tech Crash & Post-Crash & RE Bubble & RE Crash \\
\hline & $(\mathrm{N}+131)$ & $(\mathrm{N}=200)$ & $(\mathrm{N}=226)$ & $(\mathrm{N}=215)$ & $(\mathrm{N}=612)$ & $(\mathrm{N}=344)$ \\
\hline$[-\mathbf{- 6 5},+\mathbf{1}]$ & 0.36 & -9.63 & 10.32 & 1.69 & 2.41 & -3.77 \\
\hline & 0.29 & $* * *-7.68$ & $* * * 7.73$ & 1.55 & $* * * 5.22$ & $* * *-5.05$ \\
\hline$[-\mathbf{- 6 5},+\mathbf{1 0}]$ & 0.57 & -11.02 & 11.70 & 1.77 & 2.61 & -3.53 \\
\hline & 0.42 & $* * *-8.25$ & $* * * 8.22$ & 1.52 & $* * * 5.30$ & $* * *-4.43$ \\
\hline$[-\mathbf{- 1 0},+\mathbf{1}]$ & 0.53 & -2.03 & 2.48 & 0.87 & 0.31 & 0.08 \\
\hline & 0.99 & $* * *-3.82$ & $* * * 4.38$ & $* 1.88$ & 1.59 & 0.26 \\
\hline$[-\mathbf{- 1 0},+\mathbf{1 0}]$ & 0.73 & -3.42 & 3.85 & 0.94 & 0.51 & 0.33 \\
\hline & 1.03 & $* * *-4.87$ & $* * * 5.15$ & 1.54 & $* 1.96$ & 0.79 \\
\hline$[-\mathbf{- 1 , + 1}]$ & 0.09 & -0.81 & 0.96 & 0.11 & 0.00 & 0.38 \\
\hline & 0.35 & $* * *-3.06$ & $* * * 3.39$ & 0.48 & 0.03 & $* 1.97$ \\
\hline$[-\mathbf{1},+\mathbf{1 0}]$ & 0.30 & -2.20 & 2.33 & 0.81 & 0.22 & 0.62 \\
\hline & 0.55 & $* * *-4.15$ & $* * 4.13$ & 0.40 & 1.01 & $* * 2.37$ \\
\hline
\end{tabular}

* Significance at $10 \%$ level

$* *$ Significance at $5 \%$ level

*** Significance at $1 \%$ level

\section{AUTHOR INFORMATION}

Russell M. Price, Ph.D. joined the Howard University faculty in Fall 2006. He teaches courses in Macroeconomics, Financial Management, Finance Principles, Financial Modeling, Financial Markets/Institutions and Commercial Real Estate/Housing Finance. He also serves as a faculty advisor of the Howard University Real Estate Club. He holds a B.S. in Civil Engineering from Cornell University in Ithaca, NY and a Ph.D. in Finance from The Florida State University in Tallahassee, FL. His research interests include real estate finance, asset pricing, valuation, mutual funds, mortgage pricing and REITs. His research appears in the American Journal of Business Education, Journal of Real Estate Research, Journal of Business and Economic Research, Journal of the Academy of Economics and Finance and Journal of Real Estate Portfolio Management. Russell M. Price is an Assistant Professor of Finance at Howard University. Address: Howard University School of Business, Department of Finance, International Business and Insurance, Room 531, 2600 Sixth Street NW, Washington, DC 20059. Office Phone: (202) 806-1639. Office Fax: (202) 986-4409. E-mail: r_price@ @oward.edu

\section{REFERENCES}

1. Allgood, S. and K. A. Farrell (2000). The Effect of CEO Tenure on the Relation Between Firm Performance and Turnover. Journal of Financial Research, 23 (2), 373-390.

2. Barclay, M.J. and C.G. Holderness (1989). Negotiated Block Trades and Corporate Control. Working Paper, University of Rochester.

3. Bonnier, K.A. and R. F. Bruner (1989). An Analysis of Stock Price Reaction to Management Change in Distressed Firms. Journal of Accounting and Economics, 11(1), 95-106.

4. Brown, S. J. and J. B. Warner (1980). Measuring Security Price Performance. Journal of Financial Economics, 8(2), 205-258.

5. Brown, S. J. and J. B. Warner (1985). Using Daily Stock Returns: The Case of Event Studies. Journal of Financial Economics, 14(1), 3-31.

6. Casamatta, C. and A. Guembel (2010). Managerial Legacies, Entrenchment, and Strategic Inertia. Journal of Finance, 65(6), 2403-2436.

7. Coughlin, A. and R. Schmidt (1985). Executive Compensation, Management Turnover, and Firm Performance: An Empirical Investigation. Journal of Accounting and Economics, 7(1), 43-66. 
8. DeAngelo, L. E. (1988) Managerial Competition, Information Costs, and Corporate Governance. Journal of Accounting and Economics 10(1), 3-36.

9. DeAngelo, H. and L. E. DeAngelo (1989). Proxy Contests and the Governance of Publicly Held Corporations. Journal of Financial Economics, 23(1), 29-59.

10. DeFond, M., and C. Park (1999). The effect of competition on CEO turnover. Journal of Accounting and Economics, 27(1), 35-56.

11. Denis, D. J. and D. K. Denis (1995). Performance Changes Following Top Management Dismissals. Journal of Finance, 50(4), 1029-1057.

12. Denis, D. J., D. K. Denis and A. Sarin (1997). Ownership Structure and Top Executive Turnover. Journal of Financial Economics, 45(2), 195-221.

13. Devos, E., A. Prevost and J. Puthenpurackal (2009). Are Interlocked Directors Effective Monitors?. Financial Management, 38(4), 861-887.

14. Fama, E. F. (1980). Agency Problems and the Theory of the Firm. Journal of Political Economy, 88(2), 288-307.

15. Fama, E. F. and M. C. Jensen (1983). Separation of Ownership and Control. Journal of Law and Economics, 26(2), 301-325.

16. Farrell, K. A. (2000). The Consequences of Forced CEO Succession for Outside Directors. Journal of Business, 73(4), 597-627.

17. Fee, C.E., and C.J. Hadlock (2000). Management turnover and product market competition: empirical evidence from the U.S. newspaper industry. Journal of Business, 73(2), 205-243.

18. Fee, C. E. and C. J. Hadlock (2003). Raids, Rewards and Reputations in the Market for Managerial Talent. Review of Financial Studies, 16(4), 1315-1357.

19. Fee, C. E. and C. J. Hadlock (2004). Management Turnover Across the Corporate Hierarchy. Journal of Accounting and Economics, 37(1), 3-38.

20. Fischer, P.E., J.E. Gramlich, P.E. Miller, and H.D. White (2009). Investor perceptions of board performance: Evidence from uncontested director elections. Journal of Accounting and Economics, 48(2/3), 172-189.

21. Furtado, E.P. and V. Karan (1990). Causes, Consequences, and Shareholder Wealth Effects of Management Turnover: A Review of the Empirical Evidence. Financial Management, 19(2), 60-75.

22. Ghosh, C. and C. F. Sirmans (2003). Board Independence, Ownership Structure and Performance: Evidence from Real Estate Investment Trusts. Journal of Real Estate Finance and Economics, 26(2/3), 287-318.

23. Gilson, S., (1989). Management turnover and financial distress. Journal of Financial Economics, 25(2), 241-262.

24. Goyal, V. and C. Park (2002). Board leadership structure and chief executive turnover. Journal of Corporate Finance, 8(1), 49-66.

25. Hadlock, C.J. and G. Lumer (1997). Compensation, turnover, and top management incentives: historical evidence. Journal of Business, 70(2), 153-187.

26. Huson, M., R. Parrino and L. Starks (2001). Internal monitoring mechanisms and CEO turnover: a longterm perspective. Journal of Finance, 56(6), 2265-2297.

27. Kang, J. and A. Shivdasani (1995). Corporate governance and top executive turnover in Japan. Journal of Financial Economics, 38(1), 29-58.

28. Klein, A. and J. Rosenfeld (1988). Targeted Share Repurchases and Top Management Changes. Journal of Financial Economics, 20(1), 493-506.

29. Martin, K. J. and J. McConnell (1989). Corporate Performance, Corporate Takeovers and Management Turnover. Working Paper, Purdue University.

30. Mikkelson, W. and M. Partch, (1997). The decline of takeovers and disciplinary managerial turnover. Journal of Financial Economics, 44(2), 205-228.

31. Murphy, K.J. and J. Zimmerman, J. (2003). Financial performance surrounding CEO turnover. Journal of Accounting and Economics, 16(3), 273-315.

32. Parrino, Robert (1997). CEO Turnover and Outside Succession: A Cross-Sectional Analysis. Journal of Financial Economics, 46(2), 165-197.

33. Reinganum, M.R. (1985). The Effect of Executive Succession on Stockholder Wealth. Administrative Science Quarterly, 30(1), 46-60. 
34. Shivdasani, A. and D. Yermack (1999). CEO Involvement in the Selection of New Board Members: An Empirical Analysis. Journal of Finance, 54(5), 1829-1853.

35. Shleifer, A. and R. W. Vishny (1986). Large Shareholders and Corporate Control. Journal of Political Economy, 19(3), 461-488.

36. Warner, J. B., R. L. Watts, and K.H. Wruck (1988). Stock Prices and Top Management Changes. Journal of Financial Economics, 20(1), 461-492.

37. Weisbach, M. S. (1988). Outside Directors and CEO Turnover. Journal of Financial Economics, 20(1), 431-460. 